\title{
The Role of Electronic Procurement in Enhancing Responsiveness of Procurement Management: An Empirical Study on Selected Mining Companies in Ghana
}

\author{
Helena Mary Boakye David Asante Eric Boafo Dadzie \\ Faculty of Business Studies, Takoradi Technical University, PO box 256, Takoradi, Ghana
}

\begin{abstract}
The emergence of electronic procurement system has revolutionized the discipline of procurement management. To date, however, very little research has been carried on this subject at the Ghana mining industry. This paper examines the level of adoption and role of e-procurement in enhancing responsiveness of procurement management at the mining industry, Ghana. Purposive random sampling was employed to select 26 respondents from 13 large scale mining companies on which structured questionnaires were administered and analyzed using linear regression. The rate of e-procurement adoption appears low at the Ghana mining sector, which the study has unveiled. Quantitatively $24 \%\left(\mathrm{R}^{2}=0.24\right)$ part of the companies' procurement process is being enhanced by eprocurement systems, yet resulting in efficiency and effectiveness in their procurement management. The companies' pilot e-procurement systems with manual system to get procurement executed though much into the orthodox manual system relatively. It is then recommended that the mining companies intensify usage of eprocurement systems to get the optimum impact on procurement management responsiveness.
\end{abstract}

Keywords: E-procurement, E-procurement Adoption, procurement management, Mining sector, Ghana.

DOI: $10.7176 / \mathrm{EJBM} / 11-25-07$

Publication date:September $30^{\text {th }} 2019$

\subsection{Introduction}

E-procurement has recently gained dominance in many organizations worldwide due to technological advancements which have made business operations easier, faster and more efficient in today's competitive global village. It encompasses all activities involved in obtaining goods and services and managing their inflow into an organization toward the end user through the internet (Lee et al, 2007). It also refers to the use of internet-based system to carry out individual or all stages of procurement process, including search, sourcing, negotiation; ordering, receipt, and post-purchase review (Croom \& Brandon, 2004). This has been facilitated by the growth in information and communication technology which has led to electronic commerce, commonly referred to as ecommerce. The growth in e-commerce has been significant in the adoption of new supply chain-related technology and applications by organizations globally. Like other functions embraced by e-commerce, the procurement function has positively been impacted with a predicted growth in e-procurement applications covering both transactional buying and strategic sourcing activities (Greunen et al., 2010).

In the European Union, e-procurement for the public sector was first introduced with the Directives 2004/17/EC and 2004/18/EC of 31 March 2004. These Directives, which were subsequently revised in 2014, set up the framework for transparent and equal opportunities for public procurement including the mandatory use of electronic communication for publishing opportunities, the standardization of procurement processes, electronic tender submission procedures, handling of objections etc for all public procurement made in the EU above certain thresholds. It is now evident that the electronic technologies that have revolutionized organizational processes in the last decade is e-procurement and there is growing interest in the adoption of e-procurement by both private and public sector organizations. However, this interest has faced reservations considering that e-procurement is a recent phenomenon (Hamner et al., 2009). E-procurement systems aid in reducing transaction costs by automating processes, thus replacing human labor with information technology (Hawking et al., 2010). Hossein et al. (2014) found that the emergence of internet meant that companies started turning their procurement activities towards internet since it would benefit them if all procurement processes are carried out correctly, efficiently and properly. In essence, e-procurement has the capacity to act as an integrative technology that enables integration and improvement of processes between departments in the supply chain.

In the recent years organizations are becoming more discerning about e-procurement decisions that need to be made and how they respond to the multitude of pressures and influences. Some externally hosted e-procurement services are clearly part of the growing trend as they specialize on industry sectors, like the oil and gas, pharmaceutical and mining industries all of which embraces e-procurement more than some other sectors though large corporations elect to manage their e-procurement in house (World Bank 2017). A number of public agencies worldwide have identified electronic procurement (e-procurement) as a priority e-government agenda and have implemented or are in the process of implementing buyside e-procurement systems (Hawking et al., 2004). Abdi found that most commercial state corporations in Kenya have adopted the e-procurement system even though 
several procurement functions are still carried out in the traditional manual system (Abdi, 2009). Though the pace for the implementation is still very slow in Ghana, the Public Procurement Authority has made many strides in the initiation of e-procurement evidenced by April, 2019 lunch by the government. Addison (2017) results indicate that Ghanaian public sector is well informed of the e-procurement process, though the patronage is low. Public sector's e-procurement seems to have gain enormous attention among which is discussed in the empirical to unveil the quest for the present study.

\subsubsection{Empirical Studies}

Adams (2014) assessed potential of electronic procurement at the public sector, Ghana. The aim was to explore challenges in manual procurement system, investigate prospects in the E-procurement and implementation challenges using structured questionnaire on public agencies within Accra Metropolis. E-procurement was identified with challenges among which is technology related yet the system helps in cutting cost across the procurement process. Focus of the study was on public entities which have almost become the sole area of interest in most contemporal studies.

Noor et al (2013) also examined the role of e-procurement strategy in enhancing procurement performance in Kenya state corporations as a descriptive research design. They saw E-procurement useful for its cost reduction ability on Kenya state corporations. They found that E-procurement technology and other advanced technologies are essentially freeing procurement professionals to become true supply managers at the enterprise, adding to the role of procurement shifting from reducing cost to creating supply value for companies (Noor et al 2013). They collected data through questionnaire and analyzed quantitatively using descriptive statistics and inferential analysis. Among e-procurement roles captured in the study includes enhancement in customer service level, auditability and compliance, inventory optimization, and buyer supplier collaboration. In a first instance, the study was carried on Kenya public agencies hence signals a probable difference in outcome if similar study should be carried on a different environment or sector. This serves as a gap on the study. Further gap was the lack of operational direction to determining enhancement in procurement performance. Kalakota and Robinson, (2001) states that the benefits of e-procurement fall in two major categories viz. efficiency and effectiveness (see section 2.1.3). It is believed that the suggestions of the later scholars give concise parameters to have operationalized procurement performance enhancement in such a quantitative study of Noor et al, (2013).

At the Lisbon summit in 2000, it was decided that EU should pay special attention to e-procurement. It was emphasized that "The emergence of the new Information and Communication Technologies (ICTs) offer promising opportunities as regards the efficiency, transparency and opening-up of public procurement" (European Commission, 2000). E-Procurement on the public sector has even been on political agenda in EU for a while

There is a growing interest over e-procurement at the public sector. Few literatures exist on the phenomenon at the private sector, especially the Mining industry. Drawing on the reviews above, the present study focuses on Ghana mining industry to examine two major objectives: a] level of e-procurement adoption at the mining industry and $\mathrm{b}$ ] role of e-procurement to enhancing responsiveness of the companies procurement Management.

\subsubsection{Significance of the study}

Driven by the increasing trend toward purchasing inputs and other raw materials from outside the organization, implementing electronic procurement (e-procurement) has become a significant tactic in most companies' ebusiness strategies, Deloitte Consulting,( 2001) has stated. Therefore this study will not only be an eye opener to mining companies but also other private corporations, researchers and students on the key contribution of eprocurement to procurement management.

\subsection{Literature Review \\ 2.1 Defining E-procurement}

Parida and Parida (2005) define e-procurement as a technology solution that facilitates corporate buying using the Internet. Essentially an Internet/Intranet based purchasing application or hosted service that streamlines buying, trading partners, maximizes trade efficiency across the entire supply chain, and provides strategic e-commerce capabilities in Internet time; Gimenez and Lourenço (2004) said E-procurement is a process which supports the procurement and sourcing activities via Internet technologies and enables an efficient negotiation between buyers and suppliers; Turban and King (2006) sees it as Electronic acquisition of goods and services in a firm; The automation of the procurement processes so that the sourcing, vendor selection, procurement processes, shipment status tracking and payments can be made in an online environment (Bhaskar 2005). According to European Bank for Reconstruction and Development (2015), E-procurement (i.e. electronic procurement, also known as supplier exchange) is a business-to-business or business-to-consumer or business -to-government purchase and sale of supplies, work and services through the internet as well as other information and networking systems, such as electronic data interchange and enterprise resource planning (ERP). Corsi (2006) defined e-procurement as the use of electronic methods over the internet to conduct procurement functions: identification of requirement, tendering process, payment and contract management. Scholars have defined E-procurement differently for some time now. That notwithstanding none denies the fact that it's an internet based interaction between a firm and a supplier 
resulting in effective purchases.

Citing the words of Croom \& Brandon-Jones, (2004), this paper views E-Procurement as the use of Internetbased (integrated) information and communication technologies (ICTs) to carry out individual or all stages of the procurement process including search, sourcing, negotiation, ordering, receipt, and post-purchase review. To the in-depth, E-procurement is more than just a system for making purchases online. A properly implemented Eprocurement system can connect companies and their business processes direct with suppliers whilst managing all interactions between them. This includes management of correspondence, bids, questions and answers, previous pricing and multiple emails sent to multiple participants as all eases the normal procurement process. This paper is built on the theory that Adoption of E-procurement enhances responsiveness in procurement management. Eprocurement enhances inter organizational coordination resulting in transaction cost savings and competitive sourcing opportunities for the buyer organization (Subramaniam and Shaw, 2002).

\subsubsection{Concept of E-procurement}

With increasing use of e-commerce, procurement is going through a revolution. Procurement is migrating from traditional paper-based process to e-procurement with the increasing use of Internet and E-commerce technology (Chong et al., 2002). The main function of e-procurement system is that it allows individual employees to order goods directly from their personal computers through the web on a real-time basis. Requests and orders are channeled through various forms of hubs or database. It also allows individual employees to search for items, checks availability, place and track orders and initiate payment of delivery (Ovans, 2000). E-procurement includes purchasing, transportation, warehousing and inbound receiving (Kalakota and Robinson, 2001). Generally eprocurement system has two essential components: $\bullet$ Internal processing which is corporate intranet and $\bullet$ External communication processing which is an internet-based platform (Crooms and Johnston, 2003). The two views regulate procurement processes within and without the spectrum of an organization.

The e-procurement value chain consists of indent management, e-Informing, e-Tendering, e-Auctioning, vendor management, catalogue management, Purchase Order Integration, Order Status, Ship Notice, e-invoicing, e-payment, and contract management. Indent management is the workflow involved in the preparation of tenders. This part of the value chain is optional, with individual procuring departments or organization defining their indenting process. So e-Procurement implementations involve a mixture of different models, either represents organizations acceptance of e-procurement in the context of this study. Elements of e-procurement include request for information, request for proposal, request for quotation, $\mathrm{RFx}$ (the previous three together), and eRFx (software for managing RFx projects) (Humboldt State University,2015) which all contribute to effectiveness in the eprocurement process. Section 2.1.2 discusses level of adoption of e-procurement so far.

\subsubsection{Level of Adoption of E-procurement}

There is a growing interest in the adoption of e-procurement by private and public sector organizations in the last decade. However, this interest has been with many reservations since e-procurement is a recent phenomenon. (Dai \& Kauffman, 2001; Koorn, Smith \& Mueller, 2001), E-procurement is constantly receiving lots of attention from companies in global markets. Although the benefits of e-procurement are plenty, the reality is that it is not being adapted to the much extent in developing countries (Vijaykumar, 2014). Many developing countries that face the problem of public sector corruption have failed to successfully adopt e-Government systems, including eProcurement. Den-mark was among the forerunners in Europe, but the adoption of the public e-procurement portal (PePP) has been slow despite awareness of potential efficiency gains of IT in public procurement functions, political-structural factors slow down the adoption process (Helle \& Volker,2005). So far literature has done little towards unveiling actual percentage of companies using e-procurement either at the public or private sector. This further buttresses a need for the present study on the Mining industry.

The Mining industry of Ghana accounts for 5\% of the Ghana's GDP and minerals make up 37\% of total exports, of which gold contributes over $90 \%$ of the total mineral exports. The country has 23 large-scale mining companies producing gold, diamonds, bauxite and manganese, and, there are also over 300 registered small scale mining groups and 90 mine support service companies. It is worth researching the adoption of the industry towards this revolution in procurement to enhancing mining operations.

Klein et al. (2001:811) described adoption as a decision to use an innovation within the organization, while Rogers (2003) defined adoption as a decision to make full use of an innovation (p.177). Rogers also made it clear that the decision to adopt an innovation consists of five phases of awareness, interest, evaluation, trial and adoption (Rogers, 2003). Further, Woodside and Biemans (2005:384-385) described adoption as "the decision-making process of an individual unit to adopt and use a product or service. Therefore, in this study, e-Procurement adoption refers to the actual use of web-based technologies, tools or processes to support the execution of some or all aspects of the mining procurement activities including supplier search, sourcing, negotiation, ordering, receipt, and/or post-purchase review etc. The paper measures adoption as a continuous variable using 5-point likert scale ranging from "strongly disagree to strongly agree" responses. The next section reviews benefits of e-procurement identified in previous studies and proposes the main benefits commonly referred in literatures on generic view. 


\subsubsection{Role of E-procurement}

There is no doubt that the use of the Internet in e-Procurement provides several advantages over earlier interorganizational tools. For example, Electronic Data Interchange has been providing automated purchasing transactions between buyers and their suppliers since it was launched in the 1960s. Enterprise Resource Planning (ERP) followed in the 1970s, and then came the commercial use of the Internet in 1980s. This was followed by the universal application of the World Wide Web in the 1990s (Office of Government Commerce, 2002)

According to the Epiq Technologies (2010) report, the adoption of e-procurement technology in an organization enables a firm to organize its interactions with its most crucial suppliers, a set of built-in monitoring tools to help control costs, assure maximum supplier performance and keeping an open line of communication with potential suppliers during a business process. The system allows managers to confirm pricing and leverage previous agreements to assure each new price quote is more competitive than the last. E-Procurement helps with the decision-making process by keeping relevant information neatly organized and time-stamped. Most are template-driven which makes all transactions standardized and traceable.

Literature identified a number of benefits arising from the introduction of e-procurement which have been summarized as follows: reduced price (of goods and services), reduced administrative cost, reduced inventory cost, improved financial control and compliance, (McConnell, 2009). Some other benefits of e-procurement include: an increase in contract compliance, leveraging procurement spend and cutting processing costs. A study by Chan and Lee (2002) found that organizations which adopted e-procurement strategies have reduced costs through transactional and process efficiencies and thereby promoting their procurement performance. More and more companies are conscious of the needs to introduce Internet-based technologies in their order process, due to the benefits of saving transaction cost, increasing competitive sourcing opportunities, and enhancing interorganizational coordination. Product standardization internal customer satisfaction can be enhanced through Eprocurement due to the product variety concept. This can be achieved by reducing the number of different components and or the number of suppliers via set product standards. E-procurement enhances inter organizational coordination resulting in transaction cost savings and competitive sourcing opportunities for the buyer organization (Subramaniam and Shaw, 2002, ibid). There are series of benefits linked with e-procurement in studies (Deloitte Consulting, 2001).

According to (Kalakota and Robinson, 2001), the benefits of e-procurement fall into two major categories viz. efficiency and effectiveness. Efficiency includes lower procurement costs, faster cycle times, reduced maverick or unauthorized buying, more highly organized information and tighter integration of the procurement function with key back-office systems. Effectiveness includes increased control over the supply chain, proactive management of key procurement data and higher-quality purchasing decisions within organizations. The present study operationalizes Procurement Management 'responsiveness' with how efficient and effective procurement process has turn (as a continuous variable) at the mining sector, following their adoption to e-procurement, Citing Kalakota and Robinson (2001). The variables were measure on a 5-point likert scale.

\subsection{Methodology}

A descriptive research design was used in this study. The target population of this study comprises of Procurement and ICT managers across all the 23-large scale mining companies in Ghana comprising of a total of 46 respondents from which 13 companies were selected on the basis of convenience. In essence, 26 top managers were sampled for this study. Thus E-procurement strategy and its application are relevant at this level prompting the choice of their departments. Primary data was collected using a questionnaire covering the level of adoption and role of Eprocurement in enhancing the mining companies' procurement management. Quantitative data was analyzed by employing regression test using statistical package for social science (SPSS) version 20.

\subsection{Result Presentation and Discussion}

From the 26 sampled respondents' responses, findings are being presented as follows using linear regression test statistic.

Table2: Regression Model Summary

\begin{tabular}{|c|c|c|c|c|c|c|c|c|}
\hline \multirow[b]{2}{*}{$\mathrm{R}$} & \multirow[b]{2}{*}{$\mathrm{R}^{2}$} & \multirow[b]{2}{*}{$\begin{array}{c}\text { Adjusted } \\
\mathrm{R}^{2}\end{array}$} & \multirow[b]{2}{*}{$\begin{array}{l}\text { Std. } \\
\text { Error }\end{array}$} & \multicolumn{5}{|c|}{ Change Statistics } \\
\hline & & & & $\begin{array}{c}\mathrm{R}^{2} \\
\text { Change }\end{array}$ & F Change & df1 & $\mathrm{df} 2$ & $\begin{array}{c}\text { Sig. F } \\
\text { Change }\end{array}$ \\
\hline $.520^{\mathrm{a}}$ & .270 & .240 & .653 & .270 & 8.878 & 1 & 24 & .007 \\
\hline
\end{tabular}

\section{a. Predictors:(Constant), e-procurement adoption b. Dependent variable: PM responsiveness}

According to table 2, 24\% rate of responsiveness in procurement management (PM) can be explained by the linear relationship between the predictor and the criterion variable i.e. e-procurement adoption and PM responsiveness. E-procurement contributes but little to effectiveness and efficiency in companies PM at the mining industry today. Seventy-six percent of responsive rate in the firms' PM cannot be aligned to e-procurement adoption justifies with significant $\mathrm{P}$-value $0.007<\alpha=0.05$; hence, there is enough statistical evidence to establish 
that responsiveness in PM at the mining sector is not utterly defined by E-procurement adoption.

\subsection{Discussion and practical implication of Result}

Procurement management seems responsive at the Ghana mining companies though with low adoption to eprocurement. Perhaps the traditional process is being managed with high diligence and control. The companies pilot electronic procurement with the orthodox system of buying though more into the orthodox as of now. Literature states procurement is migrating from traditional paper-based process to e-procurement with the increasing use of Internet and E-commerce technology (Chong et al., 2002 ibid). Full switch reflection is yet to be seen following the cited study. Elsewhere Abdi found that most commercial state corporations in Kenya adopt eprocurement system even though several procurement functions are still carried out in the traditional manual system (Abdi, 2009 ibid), which infers low adoption. Though the pace for e-procurement implementation is still very slow in Ghana, the Public Procurement Authority is making many strides in the initiation of e-procurement evidenced with April 2019 lunch by the government. Addison $(2017$ ibid) has said already that Ghana public sector is well informed of the e-procurement process, though the patronage is low. All the cited studies never despised institutions effort to embracing e-procurement though the effort is still at the tender stage.

The Ghana mining industry also unveils similar gesture in the e-procurement discourse today. This is made explicit in matching to studies from scholars cited. So practically e-procurement is enhancing procurement management at the mining sector though it is still at the crawling phase to replacing the manual system. Quantitatively it may be worth saying $24 \%$ of the procurement process at the Mines is being facilitated by eprocurement. Of course one may argue the e-system is having weak impact however, it is resulting in efficiency and effectiveness in procurement processes of the companies which partly confirms the claim that 'E-procurement enhances inter organizational coordination resulting in transaction cost savings and competitive sourcing opportunities for the buying organization' (Subramaniam and Shaw, 2002).

The findings here imply that the mining industry engage electronic system on few activities in their procurement process and handles the rest manually, likewise Abdi (2009). Section 2.1.3 highlights various benefits the firms' stance to enjoy with e-procurement contribution to achieving efficiency and effectiveness in their procurement management processes (see; Kalakota and Robinson, 2001).

\subsection{Conclusion}

Procurement has traditionally involved slow manual procedures and even slower systematic processes for handling procurement transactions (Hawking et al., 2004). This is gearing firms' endorsement with e-procurement today. Literature identified a number of benefits arising from the introduction of e-procurement yet the adoption rate appears low at the Ghana mining industry. $24 \%\left(\mathrm{R}^{2}=0.24\right)$ of the procurement process is facilitated by eprocurement, resulting in little efficiency and effectiveness in the procurement management of the Mining companies. E-procurement is contributing to speed and accuracy going through procurement process at the mining industry though with low adoption rate. It is recommended that the companies intensify usage of the e-procurement systems so as to optimize its benefit on procurement Management. This paper covered only 13 of 23 large scale mining firms in Ghana. Posterity studies can increase the sample size and perhaps incorporate small scale mining and other mining support firms to confirm this finding. Moreover, Scholars may afford testing the finding of this study on other industries or carry similar study in other countries in effort to contributing to theoretical understanding of the phenomenon at the mining sector.

\section{References}

Laffont, J.J. \& Tirole, J. (1993), A Theory of Incentives in Procurement and Regulation. MIT Press. ISBN 9780262121743.

Lewis, M.A. \& Roehrich, J.K. (2009), Contracts, relationships and integration: Towards a model of the procurement of complex performance. International Journal of Procurement Management, 2(2):125-142.

CIPS in partnership with Profex Publishing, Procurement and Supply Operations, (2012), revised 2016, pp. 1-2

CIPS, Procurement Glossary - F Archived 14 April 2017 at the Wayback Machine, accessed 14 March 2017

Mason, L. (2018), Contract Administration, Chartered Institute of Procurement \& Supply, p. 114

Jaggaer, How do you optimize addressable spend?, published 24 May 2016, accessed 16 January 2018

"What's the difference between an RFI, an RFP, and an RFQ?". Humboldt State University. Archived from the original on 2015-07-21. Retrieved 2015-07-28

McConnell, D. J. (2009), "Analysis into the Factors Affecting the Uptake of Application of E-Procurement within the UK Publics Sector" Published Doctoral thesis.

Adams, S. (2014), "Assessing the Potential of Electronic Procurement in the Public Sector: The Case of Accra Metropolis" Kwame Nkrumah University of Science And Technology College Of Architecture And Planning department Of Building Technology

Nutakor, F. (2016), "Challenges with the Implementation of Sustainable Procurement Practices in the Mining 
Industry. (A Case Study of Some Selected Mining Firms in Western Region of Ghana)"

Ovans, A. (2000), E-procurement at schlumberger. Harvard Bus. Rev.

Presutti, W.D. (2003), Supply management and e-procurement creating value added in the supply chain. Ind. Market. Manage., 32: 219-226. DOI: 10.1016/S0019-8501(02)00265-1

Kalakota, R. \& Robinson, M. (2001), E-business 2.0:Roadmap for Success. 1st Edn., Addison-Wesley Professional, Boston, ISBN-10: 0201721651, pp: 520.

Helle, Z. H. \& Volker, M. (2005), "E-Procurement Adoption in the Danish Public Sector" The Influence of Economic and Political Rationality; Copenhagen Business School, Denmark

Klein, K. J., Conn, A. B., \& Sorra, J. S. (2001), Implementing Computerized Technology: An Organizational Analysis. Journal of Applied Psychology, 86(5), p.811-824. doi: https://doi.org/10.1037/0021-9010.86.5.811

Rogers, E.M. (2003), “'Diffusion of Innovations (5th ed.). New York: Free Press”

Dai, Q. \& Kauffman, R. J. (2001), "Business Models for Internet-Based E Procurement Systems and B2B Electronic Markets: An Exploratory Assessment.” A paper presented at the Thirty-Fourth Annual Hawaii International Conference on Systems Sciences, January 3-6, Maui, HI.

Koorn, R., Smith, D. \& Mueller, C. (2001), E-Procurement and Online Marketplaces. Amsterdam, the Netherlands: Compact.

Subramaniam, C. \& Shaw, M. (2002), A study of value and impact of B2B e-commerce: the case of web-based procurement. International Journal of Electronic Commerce, 6 (4), 19-40

Abdi, K. A., (2009), "Electronic Procurement and organizational performance among Commercial State Corporations" A research project presented in partial fulfillment of the requirements for the award of master of business administration, school of business of the university of Nairobi

Corsi, M. (2006), “E-Procurement Overview”. Università "La Sapienza” di Roma

European Commission (2000) Directive of the European Parliament and of the Council. On the coordination of procedures for the award of public supply contracts, public service contracts and public works contracts. In: (COM (2000) 275).

Chong, P.P., Chen, E. T. \& Chen, C. H. J. (2002), E-Procurement in taiwan: Issues and viewpoints. Rev. Pacific Basin Finan. Markets Pol., 5: 521-531. DOI:10.1142/S0219091502000912

Vijaykumar R. S, \& Zonal, M. (2014), "Exploratory Study of E-Procurement Adoption in Indian and Chinese Companies: Case Study with Innovation Approach" American Journal of Economics and Business Administration 5 (3): 107-115, 2013 ISSN: 1945-5488 